\title{
nam \\ Life Cycle and Phylogeography of True Truffles
}

\author{
Jiao Qin ${ }^{1}\left(\mathbb{D}\right.$ and Bang Feng ${ }^{2,3, * \mathbb{C}}$
}

1 Key Laboratory of Economic Plants and Biotechnology, Kunming Institute of Botany, Chinese Academy of Sciences, Kunming 650201, China; qinjiao@mail.kib.ac.cn

2 CAS Key Laboratory for Plant Diversity and Biogeography of East Asia, Kunming Institute of Botany, Chinese Academy of Sciences, Kunming 650201, China

3 Yunnan Key Laboratory for Fungal Diversity and Green Development, Kunming 650201, China

* Correspondence: fengbang@mail.kib.ac.cn

check for

updates

Citation: Qin, J.; Feng, B. Life Cycle and Phylogeography of True Truffles. Genes 2022, 13, 145. https://doi.org/ 10.3390/genes 13010145

Academic Editor: Fernando Leal

Received: 13 December 2021

Accepted: 11 January 2022

Published: 14 January 2022

Publisher's Note: MDPI stays neutral with regard to jurisdictional claims in published maps and institutional affiliations.

Copyright: () 2022 by the authors. Licensee MDPI, Basel, Switzerland. This article is an open access article distributed under the terms and conditions of the Creative Commons Attribution (CC BY) license (https:// creativecommons.org/licenses/by/ $4.0 /)$.

\begin{abstract}
True truffle (Tuber spp.) is one group of ascomycetes with great economic importance. During the last 30 years, numerous fine-scale population genetics studies were conducted on different truffle species, aiming to answer several key questions regarding their life cycles; these questions are important for their cultivation. It is now evident that truffles are heterothallic, but with a prevalent haploid lifestyle. Strains forming ectomycorrhizas and germinating ascospores act as maternal and paternal partners respectively. At the same time, a number of large-scale studies were carried out, highlighting the influences of the last glaciation and river isolations on the genetic structure of truffles. A retreat to southern refugia during glaciation, and a northward expansion post glaciation, were revealed in all studied European truffles. The Mediterranean Sea, acting as a barrier, has led to the existence of several refugia in different peninsulas for a single species. Similarly, large rivers in southwestern China act as physical barriers to gene flow for truffles in this region. Further studies can pay special attention to population genetics of species with a wide distribution range, such as $T$. himalayense, and the correlation between truffle genetic structure and the community composition of truffle-associated bacteria.
\end{abstract}

Keywords: life cycle; mating type; genetic structure; glaciation; river isolation; ascocarp-associated bacteria

\section{Introduction}

True truffles refer to hypogenous ascocarps produced by species of the genus Tuber. This genus consists of 11 major phylogenetic clades [1] and approximately 200 species [2], and plays an important ecological role as an ectomycorrhizal partner of several plant families, such as Fagaceae and Pinaceae [2]. Many true truffles from Europe, such as T. melanosporum (the Périgord black truffle), T. magnatum (the Italian white truffle), T. aestivum (the Burgundy truffle) and T. borchii (the bianchetto truffle), are highly prized edible species known for their aromatic and gustatory qualities. The Chinese black truffles, composed of T. indicum and T. himalayense, are widely collected, consumed, and exported to Europe [3]. Driven by their economic importance, many truffles, especially T. melanosporum, were successfully cultivated, not only in their country of origin, but in non-native countries, such as Australia, New Zealand, the United States and South Africa [4]. In this process, many questions have arisen regarding the life cycle of true truffles, some of which have been answered by population genetics and genomic studies on representative species, while others remain unresolved [5]. In contrast, many truffle species have a narrow distribution range. Moreover, truffles produce below-ground ascocarps and depend on truffle-hunting animals for the dispersal of spores. This raises the question of how the distribution pattern of true truffles affects their genetic structure. Many have attempted to answer this question using the powerful tool of population genetics.

In this review, we summarized more than three decades of population genetics research on true truffles, highlighting the following two issues: (1) the life cycle of true truffles, and 
(2) the genetic structure of true truffles, and its association with historical climatic and tectonic variations.

\section{A Brief History of Population Genetics Studies on True Truffles}

The origin of population genetics studies on true truffles can be traced back to the late 1980s. In 1989, Pacioni and Pomponi found great genetic stability in T. melanosporum and T. brumale by using allozyme electrophoresis; however, significant genetic heterogeneity was detected in T. aestivum and T. mesentericum [6]. Later, they analyzed the genetic patterns of T. aestivum and T. mesentericum in Italian populations using multi-locus electrophoresis, revealing that the two species can be delimited using molecular evidence [7]. Following this study, population genetics studies have been carried out in several truffle species, utilizing different types of gene makers. In brief, the genetic markers used include random amplified polymorphic DNA (RAPD) [8], simple sequence repeat (SSR, microsatellite) [9-16], amplified fragment length polymorphism (AFLP) [10], inter-simple sequence repeat (ISSR) [17], mating type loci [11-15] and single-nucleotide polymorphisms (SNPs) from different DNA fragments, such as internal transcribed spacers (ITS) [18-21], beta-tubulin gene [20] and SNPs at the genomic scale [22]. The major concerns of these studies are (1) species delimitation of several species complex, e.g., T. indicum [3,20,21], T. aestivum [23], T. borchii [24] and T. brumale [25], (2) life cycle of true truffles [9,10,13-15], and (3) genetic structure of several truffle species [16-19,25-27].

\section{Life Cycle of True Truffles}

\subsection{True Truffles Are Heterothallic}

The first question that must be answered regarding the life cycle of a fungus is its reproductive system. Generally, there are two paradigmatic sexual systems in fungi: heterothallism and homothallism [28,29]. It is expected that heterozygosity will be detected in heterothallic species while using codominant genetic markers (such as RAPD, AFLP and SSR), as such species contain both maternal and paternal genotypes. Until genomic information is available for truffle species, this is the theoretical basis for inferring the reproductive system of true truffles through population genetics studies. However, until 2005, both $T$. melanosporum and T. magnatum were considered to be self-compatible, or highly inbred species, as no heterozygous ascocarp was detected when genotyped using codominant makers $[8,19,26,30]$. Nonetheless, extensive genetic exchange was detected in T. magnatum populations [31], leading to the hypothesis that the majority of the ascocarps of T. magnatum, the so-called gleba, are composed of haploid maternal material, while ascospores, which have cell walls that are difficult to disrupt during DNA extraction, contain both paternal and maternal information. This hypothesis was supported by SSR genotyping on gleba and asci (including ascospores) separately, clearly indicating that T. magnatum is an outcross species [9]; later, the same phenomenon was reported for T. melanosporum [10]. In 2010, genome sequencing provided direct evidence that T. melanosporum, bearing only one mating type idiomorph in a single ascocarp, is heterothallic, and thus an obligate outcrossing species [32]. This was further confirmed by screening mating-type idiomorphs in different ascocarps of T. melanosporum [33]. Other species were later shown to be heterothallic based on genome sequences (T. magnatum and T. aestivum) [34], or sequences of mating type genes (T. indicum species complex [35] and T. borchii [36]).

\subsection{Ectomycorrhizal Mycelia and Germlings from Ascospores Contribute as Maternal and Paternal Partners, Respectively}

Mating-type genes were used in population genetics studies of true truffles (particularly T. melanosporum) soon after they were reported, together with SSR genotyping, a combination that has greatly improved our understanding of the life cycle of true truffles. By simultaneously genotyping ectomycorrhizas (ECMs) and ascocarps in fine-scale areas, it has been shown that gleba of ascocarps and surrounding ECMs are both formed by haploid mycelia [11,12], and that they have the same mating type profile (either MAT1-1 or MAT1-2), and the same SSR genotype, whereas ascospores show several genotypes that have never 
been detected in ECMs and gleba. This suggests that gleba, the maternal material of truffles, preferentially comes from strains that have colonized the roots of their hosts. This also raises the question of where the parental partner comes from [12]. There are some potential origins, including but not limited to: (1) mycelia from germinated ascocarps or nearby ECMs [14,15], (2) free-living mycelia in soil [15], and (3) mycelia that exist as endophytes in non-host plants [5]; Tuber melanosporum and T. aestivum can endophytically colonize roots of non-ectomycorrhizal plants $[13,37,38]$. However, it was later shown that endophytisms in both T. melanosporum and T. aestivum are of a maternal feature [13]. Instead, some studies showed that germinated ascocarps and free-living mycelia may serve as paternal material. By genotyping ascocarps consecutively over a four-year period (2010-2014), it was found that paternal genotypes, unlike maternal ones, cannot persist over the years, and cannot be detected from ECMs [14]. Therefore, Taschen et al. [14] speculated that germlings from the soil spore bank act as paternal partners, based on their own observations, and that mating type idiomorph supplemental to surrounding ECMs can rarely be detected in soil [12]. Contrasting with this study, De la Varga et al. [15] detected signals of the persistence of paternal genotypes over years, and the existence of both mating type idiomorphs in soil patches, suggesting that both germinating ascospores and soil mycelia can act as paternal genotypes; nonetheless, both studies supported that germinating ascospores may play an important role as a paternal genotype of T. melanosporum. A later study on T. borchii led to the same hypothesis [39]. Interestingly, it was found that up to $42 \%$ of fruitbodies remain unremoved in managed truffle grounds [40], indicating that there is enough spore bank in soil to act as paternal partners. Unfortunately, this still lacks direct evidence from genotyping soil DNAs, using both mating type and SSR markers. To fulfill this gap, two issues need to be addressed, (1) genotyping should be carried out in different time scales, as the time for the joining of paternal gametes is still questionable [5], and (2) technical improvements to obtain DNAs from ascospores in soil, or to separate ascospores from soil, are needed.

Here, we present a scheme for the life cycle of truffles (Figure 1), based on the above evidence. We must note that endophytism in the non-host plant likely makes no direct contribution to the formation of ascocarps; instead, it can improve the production of truffles by reducing the germination and growth of weeds [41].

\subsection{Strains with Opposite Mating Type Idiomorphs Compete for Existence on Host Roots}

In exploring the distribution pattern of mating types in natural T. melanosporum plantations, Rubini et al. [12] found identical mating types and SSR profiles under a single host plant. Furthermore, it was shown that "the minimum distance between sites where ECM of different mating types were detected was $50 \mathrm{~m}$ ", indicating a clear spatial segregation of mating types [12]. The same authors also screened the distribution patterns of mating-type idiomorphs in nursery-grown plants. The results showed that, at the beginning of inoculation with $T$. melanosporum ascocarps (six months), nearly all seedlings can form ECMs with strains featuring both mating type idiomorphs, but in nearly half of these seedlings, only one idiomorph could be detected 18 months after inoculation [12]. Similarly, a study from Australia [42] showed that the two idiomorphs were detectable in all two-year-old seedlings, while only one idiomorph was detectable in nearly half of the trees from plantations established four to ten years ago. Murat et al. [11] reported that all mycorrhizas displayed the same mating type in large soil patches of up to $15 \mathrm{~m}^{2}$, by investigating two old plantations of T. melanosporum, set up for over 15 years. These observations suggest that strains with opposite mating types compete for existence in host roots in different timelines, and result in the spatial separation of mating types. Similarly, the segregation of mating types was observed in T. aestivum, although the tendency is less pronounced than in T. melanosporum [43]. Although several hypotheses have been proposed [5,44], the reasons or mechanisms for the competition, and its potential contribution in the reproduction of truffles, remain unclear. 


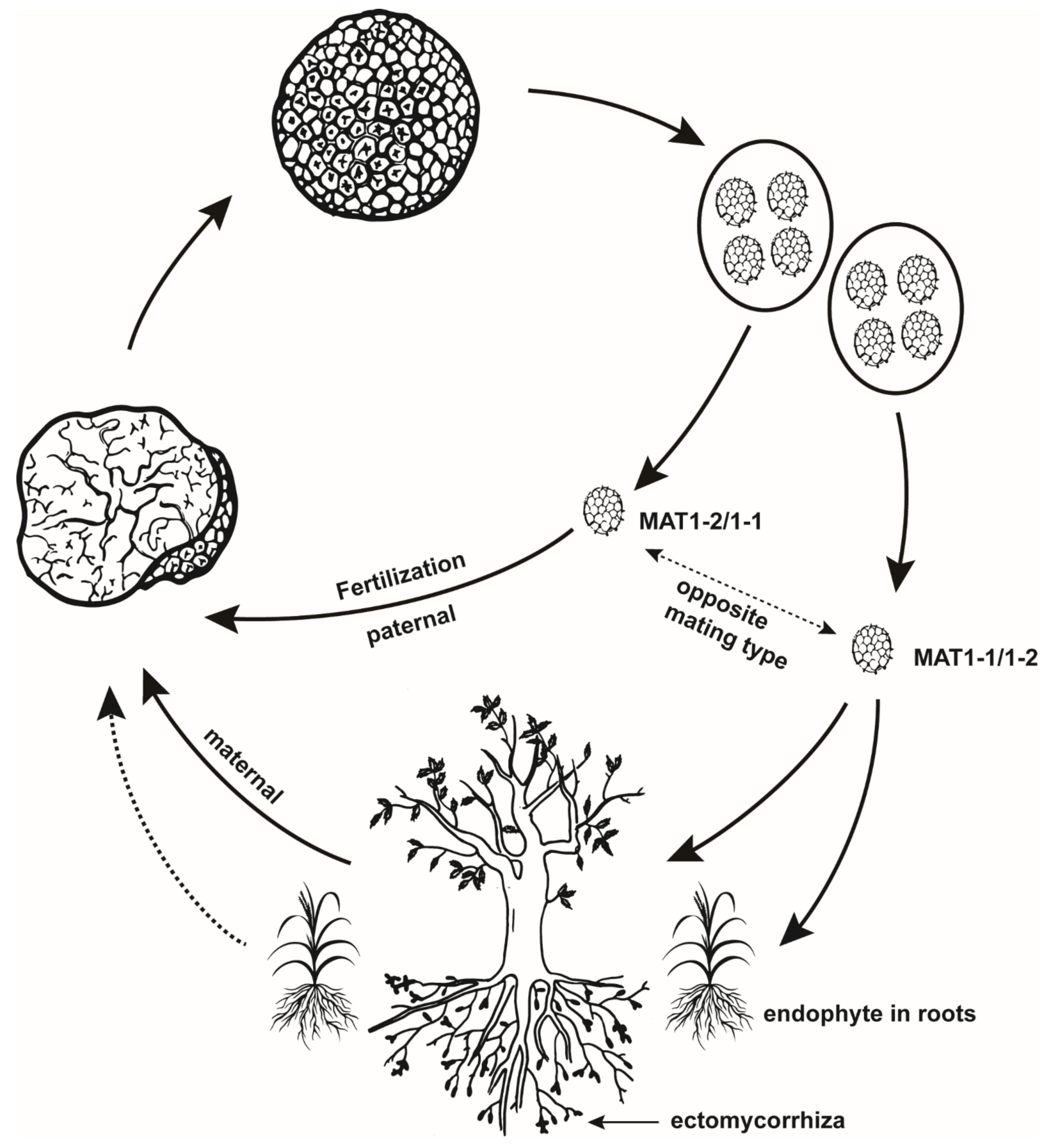

Figure 1. A scheme showing the life cycle of true truffles.

\section{Genetic Structure of True Truffles}

4.1. The Last Glaciation Has a Common Influence on the Genetic Structure of European Truffles

In addition to fine-scale population genetics studies aimed at revealing the reproductive pattern of true truffles, a number of large-scale studies have been conducted to explore their genetic diversity and genetic structure. Many European species have attracted the attention of researchers, and most studies have addressed how the last glaciation has affected the genetic structure of these truffles. Although the distribution ranges of the studied truffle species differed, and different molecular markers were used in these studies, it was shown that almost all species studied experienced a bottleneck during the glacial period, when they retreated into southernmost refugia, and a post-glacial expansion to northern areas $[10,16-19,25,27,31,45]$. 
Among these, T. melanosporum, T. magnatum, T. brumale and T. mesentericum are four species with relatively narrow distribution ranges. In T. melanosporum, analyses of Italian and French samples, using either SNPs from ITS or SSR genotyping, identified higher levels of genetic diversity in southernmost populations, supporting the Italian Peninsula as its refugium during the last glaciation [10,19]. For samples from Spain, high levels of genetic diversity could be detected in southern, central, and northern populations using ISSR genotyping, suggesting that the Iberian Peninsula may represent another refugium of this species [17]. Unfortunately, different genetic markers were used, and so those results cannot be combined to reveal the genetic structure of T. melanosporum, covering its full distribution range. Similarly, SSR genotyping suggested that the Italian $[16,31]$ and the Balkan Peninsulas [16] act as two refugia of T. magnatum. Tuber brumale, with a similar distribution pattern to T. magnatum, was proven to be a species complex containing two species, $T$. brumale and T. cryptobrumale, the latter mainly distributed in the Carpathian Basin [25,45]. A study based on SNPs from ITS sequences showed that T. brumale harbored two main haplotype groups, suggesting the existence of two refugia for this species, Eastern Europe refugium (the Balkan Peninsula) and Western Europe refugium, whereas T. cryptobrumale may have survived in the Carpathian refugium during the last glaciation [25]. Similarly, T. mesentericum can be divided into three main clades $[46,47]$ representing three cryptic species: T. mesentericum, T. bituminatum and T. suave [47]. The phylogeographic structure of the T. mesentericum species complex was not discussed in depth in the available studies $[46,47]$. Nevertheless, the narrow distribution of T. bituminatum and T. suave in southern Europe (mainly Italy) suggests that the Italian peninsula has played an important role in the speciation and maintenance of these two cryptic species. Unlike the three aforementioned species, T. aestivum can be found in Europe [27] and Turkey [48]. SSR genotyping on European samples identified four genetic groups without significant geographical isolation, indicating the existence of ecotypes [27]. In contrast, analyses on ITS sequences showed a higher level of genetic diversity in Turkish and southern European populations than in northern European populations, suggesting that Turkey and southern Europe may have acted as refugia for T. aestivum [18].

Taking all these observations together, it is evident that southern Europe, including the Iberian, Italian and Balkan Peninsulas, and Turkey have acted as refugia for different truffle species during the last glacial period (Figure 2). The existence of multiple refugia isolated by the Mediterranean Sea for a single species $[16,18]$ indicates that the Mediterranean Sea may act as a physical barrier to gene flow for truffle species. However, there is evidence of gene flow between different peninsulas for T. magnatum [16], or between Europe and Turkey in T. aestivum [18]. It was hypothesized that such migrations were introduced by land bridges [16] or by human activities [18].

\subsection{Drainage Isolation Contributes to Genetic Structure Formation of Chinese Black Truffle}

The Chinese black truffle, distributed mainly in East Asia, is one species complex that received broad interest in population genetics studies. This species complex was separated into two phylogenetic clades that represent two species: T. indicum and T. himalayense [49]. However, these two clades were also treated as two ecotypes of a single species; T. indicum, as "a west-east sinuous line between the two groups", has been observed [20]. It was later shown that both clades have a sympatric distribution in several localities [3], but harbor "sequence variations and rearrangements in both coding and non-coding regions" in their mating type idiomorphs [35], suggesting that they should be two species with significant reproductive isolations [3]. This treatment was further supported by SSR genotyping on population samples from southwestern China [21], and phylogenetic analyses on samples from China and Japan by using mating-type loci and other DNA fragments [50]. 


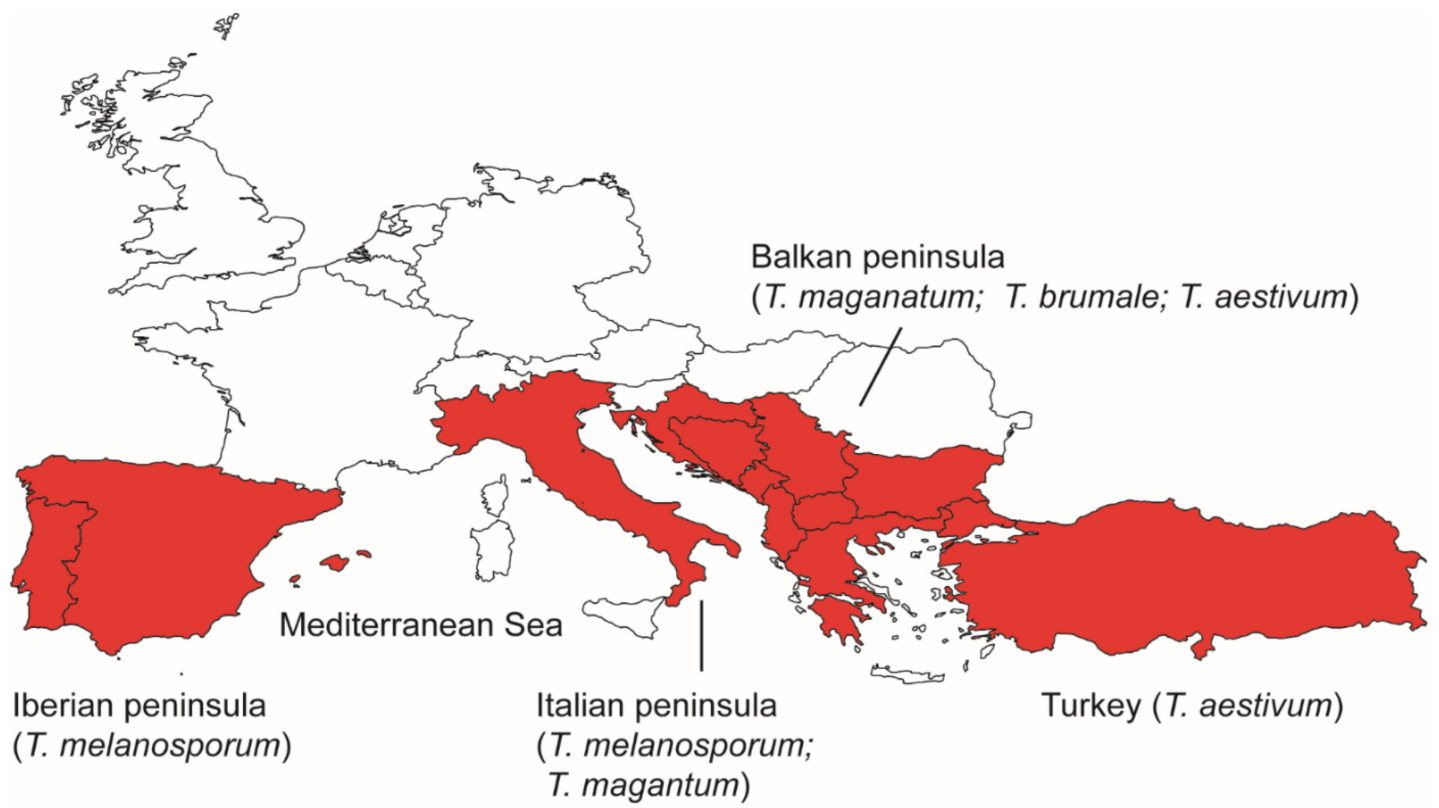

Figure 2. A map showing refugia for different European truffle species during the last glaciation.

In southwestern China, T. indicum and T. himalayense are mainly distributed in the "Three Parallel Rivers" region. Population genetics analyses using SNPs from four DNA fragments revealed three major haplotype groups, namely Group W (west), C (central) and $\mathrm{N}$ (north), isolated by the paleo-Red River and modern Jinsha River (the upper region of Yangtze River), in T. indicum (Figure 3). This indicates that both paleo and modern drainage systems have contributed to the formation of its genetic structure by acting as physical barriers to gene flows between populations. In contrast, no significant geographic structure was detected in T. himalayense, likely due to the lower evolutionary rates of this species, at least in the DNA fragments used in the population genetics study [3]. In fact, a significant "isolation by rivers" genetic structure could be detected in T. himalayense while using SNPs from the whole genome to infer the phylogeographical structure of this species (author's unpublished data). Therefore, drainage isolations have served as a key driving factor for the formation of genetic structure in both T. indicum and T. himalayense.

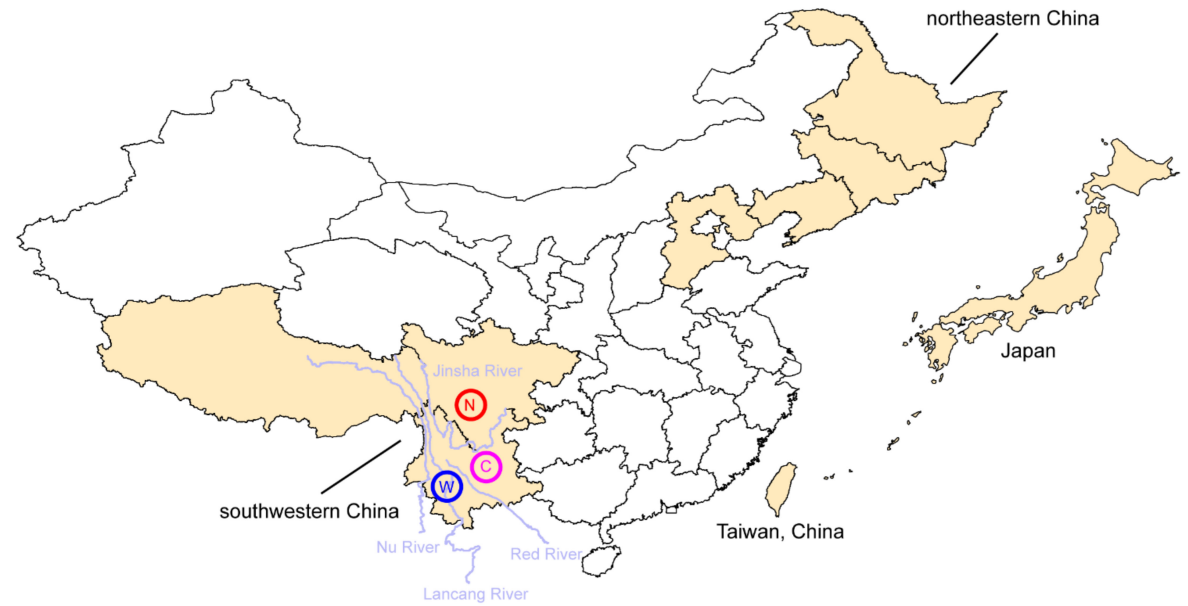

Figure 3. A map showing the distribution range (in yellow) and biogeographic patterns of Chinese black truffles. Tuber indicum can be found in southwestern China and three haplotype groups (N, north; C, central and W, west) were revealed, while T. himalayense can be found in southwestern China, northwestern China, Taiwan island of China and Japan. 
Notably, T. himalayense is distributed over a wide range in East Asia, including southwestern China, northeastern China [51], Taiwan Island of China (the so-called T. formosanum) and Japan [50] (Figure 3). This discontinuous distribution pattern makes for an ideal system for studying the evolution of truffles over a large geographic range. However, studies on this species have only been conducted in southwestern China [3,21] and Japan [52]. Further studies covering its entire distribution range would help us to better understand its evolutionary history.

\section{Conclusions and Perspectives}

After more than 30 years of research on the population genetics of true truffles, our understanding of the life cycle and genetic structure of truffle species has been improved to a great extent. It is now clear that truffle species are heterothallic but with a prevalent haploid lifestyle, similar to those of true morels (Morchella spp.) [29]. Strains form ectomycorrhizas contribute as the maternal partner, while germinating ascospores act as the paternal partner, although additional direct evidence is still needed to support this view. Concerning their genetic structure, most European truffle species retreated into the southern refugia for survival during the last glacial period, and expanded northward after glaciation. The isolation of the Mediterranean Sea could have led to the existence of several refugia in different peninsulas for a single truffle species. Similarly, large rivers in southwestern China act as physical barriers to gene flows for T. indicum and T. himalayense, thus contributing a lot to the genetic structure of these two species. However, how the discontinuous distribution of T. himalayense in China (including mainland China and Taiwan) and Japan can influence the genetic structure of this species is still an open question. This can be answered by conducting population genomics on samples gathered from different regions.

Abundant and diverse ascocarp-associated bacteria were reported from several species of true truffles, such as T. melanosporum [53-55], T. maganatum [56-58], T. aestivum [59,60], T. borchii [61], T. indicum species complex [51] and T. pseudohymalayense [62]. Remarkably, studies have shown that the genus Bradyrhizobium is dominant in most studied true truffle species [51,63], but can be rarely found in false truffes [64], and that a single Bradyrhizobium species is able to form symbiotic reactions with truffles from different continents [51]. This raises a previously unexplored question: what if truffles and their associated Bradyrhizobium species have co-evolved at the population level? Furthermore, ascocarp-associated bacteria have been shown to play a role in aroma formation $[65,66]$ and nitrogen fixation $[51,56]$. Intriguingly, it has been shown that the genetic diversity of truffles can influence the variation in their aroma $[67,68]$, and that truffle species can select their associated bacterial communities $[62,63]$. It will be interesting to explore how the community composition of ascocarp-associated bacteria, the genetic structure of truffles, and aroma variability are linked. Fortunately, it has come to our attention that the journal Diversity is preparing a Special Issue on "Genetic diversity of truffle species and soil microbial interactions". Hopefully, research work on this issue will bring us answers to the above questions.

Author Contributions: B.F. drafted the manuscript, J.Q. prepared the figures. Both authors improved the manuscript. All authors have read and agreed to the published version of the manuscript.

Funding: This work is funded by the National Natural Science Foundation of China (31770030), Yunnan Applied Basic Research Project (2017FB022) and the Yunnan Ten Thousand Talents Plan, Young \& Elite Talents (YNWR-QNBJ-2018-052).

Institutional Review Board Statement: Not applicable.

Informed Consent Statement: Not applicable.

Data Availability Statement: Not applicable.

Acknowledgments: We are very grateful to Jianping Xu from McMaster University, the guest editor of this special issue, for inviting us to write this review. Two reviewers are thanked for providing very useful suggestions. 
Conflicts of Interest: The authors declare no conflict of interest.

\section{References}

1. Bonito, G.; Smith, M.E.; Nowak, M.; Healy, R.A.; Guevara, G.; Cázares, E.; Kinoshita, A.; Nouhra, E.R.; Domínguez, L.S.; Tedersoo, L.; et al. Historical Biogeography and Diversification of Truffles in the Tuberaceae and Their Newly Identified Southern Hemisphere Sister Lineage. PLoS ONE 2013, 8, e52765. [CrossRef]

2. Bonito, G.M.; Smith, M.E. General Systematic Position of the Truffles: Evolutionary theories. In True Truffle (Tuber spp.) in the World: Soil Ecology, Systematics and Biochemistry; Zambonelli, A., Iotti, M., Murat, C., Eds.; Springer: Berlin/Heidelberg, Germany, 2016; pp. 3-18.

3. Feng, B.; Zhao, Q.; Xu, J.; Qin, J.; Yang, Z.L. Drainage isolation and climate change-driven population expansion shape the genetic structures of Tuber indicum complex in the Hengduan Mountains region. Sci. Rep. 2016, 6, 21811. [CrossRef] [PubMed]

4. Zambonelli, A.; Iotti, M.; Hall, I. Current status of truffle cultivation: Recent results and future perspect. Ital. J. Mycol. 2015, 44, 31-40. [CrossRef]

5. Le Tacon, F.; Rubini, A.; Murat, C.; Riccioni, C.; Robin, C.; Belfiori, B.; Zeller, B.; De La Varga, H.; Akroume, E.; Deveau, A.; et al. Certainties and uncertainties about the life cycle of the Périgord black truffle (Tuber melanosporum Vittad.). Ann. For. Sci. 2016, 73, 105-117. [CrossRef]

6. Pacioni, G.; Pomponi, G. Chemotaxonomy of some Italian species of Tuber. Micol. Veg. Med. 1989, 4, 63-72.

7. Pacioni, G.; Pomponi, G. Genotypic patterns of some Italian populations of the Tuber aestivum-T. mesentericum complex. My-cotaxon 1991, 42, 171-179.

8. Bertault, G.; Raymond, M.; Berthomieu, A.; Callot, G.; Fernandez, D. Trifling variation in truffles. Nat. Cell Biol. 1998, 394, 734. [CrossRef]

9. Paolocci, F.; Rubini, A.; Riccioni, C.; Arcioni, S. Reevaluation of the Life Cycle of Tuber magnatum. Appl. Environ. Microbiol. 2006, 72, 2390-2393. [CrossRef]

10. Riccioni, C.; Belfiori, B.; Rubini, A.; Passeri, V.; Arcioni, S.; Paolocci, F. Tuber melanosporum outcrosses: Analysis of the genetic diversity within and among its natural populations under this new scenario. New Phytol. 2008, 180, 466-478. [CrossRef]

11. Murat, C.; Rubini, A.; Riccioni, C.; De la Varga, H.; Akroume, E.; Belfiori, B.; Guaragno, M.; Le Tacon, F.; Robin, C.; Halkett, F.; et al. Fine-scale spatial genetic structure of the black truffle (Tuber melanosporum) investigated with neutral microsatellites and functional mating type genes. New Phytol. 2013, 199, 176-187. [CrossRef]

12. Rubini, A.; Belfiori, B.; Riccioni, C.; Arcioni, S.; Martin, F.; Paolocci, F. Tuber melanosporum: Mating type distribution in a natural plantation and dynamics of strains of different mating types on the roots of nursery-inoculated host plants. New Phytol. 2011, 189, 723-735. [CrossRef]

13. Schneider-Maunoury, L.; Deveau, A.; Moreno, M.; Todesco, F.; Belmondo, S.; Murat, C.; Courty, P.; Jąkalski, M.; Selosse, M. Two ectomycorrhizal truffles, Tuber melanosporum and T. aestivum, endophytically colonise roots of non-ectomycorrhizal plants in natural environments. New Phytol. 2019, 225, 2542-2556. [CrossRef]

14. Taschen, E.; Rousset, F.; Sauve, M.; Benoit, L.; Dubois, M.-P.; Richard, F.; Selosse, M.-A. How the truffle got its mate: Insights from genetic structure in spontaneous and planted Mediterranean populations of Tuber melanosporum. Mol. Ecol. 2016, 25, 5611-5627. [CrossRef]

15. De la Varga, H.; Le Tacon, F.; Lagoguet, M.; Todesco, F.; Varga, T.; Miquel, I.; Barry-Etienne, D.; Robin, C.; Halkett, F.; Martin, F.; et al. Five years investigation of female and male genotypes in Périgord black truffle (Tuber Melanosporum Vittad.) revealed contrasted reproduction strategies: Black truffle genetic structure. Environ. Microbiol. 2017, 19, 2604-2615. [CrossRef]

16. Belfiori, B.; D’Angelo, V.; Riccioni, C.; Leonardi, M.; Paolocci, F.; Pacioni, G.; Rubini, A. Genetic Structure and Phylogeography of Tuber magnatum Populations. Diversity 2020, 12, 44. [CrossRef]

17. García-Cunchillos, I.; Sánchez, S.; Barriuso, J.J.; Pérez-Collazos, E. Population genetics of the westernmost distribution of the glaciations-surviving black truffle Tuber melanosporum. Mycorrhiza 2013, 24, 89-100. [CrossRef] [PubMed]

18. Riccioni, C.; Rubini, A.; Türkoğlu, A.; Belfiori, B.; Paolocci, F. Ribosomal DNA polymorphisms reveal genetic structure and a phylogeographic pattern in the Burgundy truffle Tuber aestivum Vittad. Mycologia 2019, 111, 26-39. [CrossRef] [PubMed]

19. Murat, C.; Díez, J.; Luis, P.; Delaruelle, C.; Dupré, C.; Chevalier, G.; Bonfante, P.; Martin, F. Polymorphism at the ribosomal DNA ITS and its relation to postglacial re-colonization routes of the Perigord truffle Tuber melanosporum. New Phytol. 2004, 164, 401-411. [CrossRef] [PubMed]

20. Wang, Y.; Tan, Z.M.; Zhang, D.C.; Murat, C.; Jeandroz, S.; LE Tacon, F. Phylogenetic and populational study of the Tuber indicum complex. Mycol. Res. 2006, 110, 1034-1045. [CrossRef]

21. Qiao, P.; Tian, W.; Liu, P.; Yu, F.; Chen, J.; Deng, X.; Wan, S.; Wang, R.; Wang, Y.; Guo, H. Phylogeography and population genetic analyses reveal the speciation of the Tuber indicum complex. Fungal Genet. Biol. 2018, 113, 14-23. [CrossRef]

22. Payen, T.; Murat, C.; Gigant, A.; Morin, E.; De Mita, S.; Martin, F. A survey of genome-wide single nucleotide polymorphisms through genome resequencing in the Périgord black truffle (Tuber melanosporum Vittad.). Mol. Ecol. Resour. 2015, 15, 1243-1255. [CrossRef] [PubMed]

23. Mello, A.; Cantisani, A.; Vizzini, A.; Bonfante, P. Genetic variability of Tuber uncinatum and its relatedness to other black truffles. Environ. Microbiol. 2002, 4, 584-594. [CrossRef] 
24. Bonuso, E.; Zambonelli, A.; Bergemann, S.E.; Iotti, M.; Garbelotto, M. Multilocus phylogenetic and coalescent analyses identify two cryptic species in the Italian bianchetto truffle, Tuber borchii Vittad. Conserv. Genet. 2009, 11, 1453-1466. [CrossRef]

25. Merényi, Z.; Varga, T.; Geml, J.; Orczán, Á.K.; Chevalier, G.; Bratek, Z. Phylogeny and phylogeography of the Tuber brumale aggr. Mycorrhiza 2014, 24, 101-113. [CrossRef] [PubMed]

26. Mello, A.; Murat, C.; Vizzini, A.; Gavazza, V.; Bonfante, P. Tuber magnatum Pico, a species of limited geographical distribution: Its genetic diversity inside and outside a truffle ground. Environ. Microbiol. 2005, 7, 55-65. [CrossRef] [PubMed]

27. Molinier, V.; Murat, C.; Peter, M.; Gollotte, A.; De la Varga, H.; Meier, B.; Egli, S.; Belfiori, B.; Paolocci, F.; Wipf, D. SSR-based identification of genetic groups within European populations of Tuber aestivum Vittad. Mycorrhiza 2015, 26, 99-110. [CrossRef]

28. Ni, M.; Feretzaki, M.; Sun, S.; Wang, X.; Heitman, J. Sex in Fungi. Annu. Rev. Genet. 2011, 45, 405-430. [CrossRef]

29. Du, X.-H.; Yang, Z.L. Mating Systems in True Morels (Morchella). Microbiol. Mol. Biol. Rev. 2021, 85, e0022020. [CrossRef]

30. Frizzi, G.; Lalli, G.; Miranda, M.; Pacioni, G. Intraspecific isozyme variability in Italian populations of the white truffle Tuber magnatum. Mycol. Res. 2001, 105, 365-369. [CrossRef]

31. Rubini, A.; Paolocci, F.; Riccioni, C.; Vendramin, G.G.; Arcioni, S. Genetic and Phylogeographic Structures of the Symbiotic Fungus Tuber magnatum. Appl. Environ. Microbiol. 2005, 71, 6584-6589. [CrossRef]

32. Martin, F.; Kohler, A.; Murat, C.; Balestrini, R.; Coutinho, P.M.; Jaillon, O.; Montanini, B.; Morin, E.; Noel, B.; Percudani, R.; et al. Périgord black truffle genome uncovers evolutionary origins and mechanisms of symbiosis. Nature 2010, 464, 1033-1038. [CrossRef] [PubMed]

33. Rubini, A.; Belfiori, B.; Riccioni, C.; Tisserant, E.; Arcioni, S.; Martin, F.; Paolocci, F. Isolation and characterization of MAT genes in the symbiotic ascomycete Tuber melanosporum. New Phytol. 2011, 189, 710-722. [CrossRef]

34. Murat, C.; Payen, T.; Noel, B.; Kuo, A.; Morin, E.; Chen, J.; Kohler, A.; Krizsán, K.; Balestrini, R.; Da Silva, C.; et al. Pezizo-mycetes genomes reveal the molecular basis of ectomycorrhizal truffle lifestyle. Nat. Ecol. Evol. 2018, 2, 1956-1965. [CrossRef] [PubMed]

35. Belfiori, B.; Riccioni, C.; Paolocci, F.; Rubini, A. Mating Type Locus of Chinese Black Truffles Reveals Heterothallism and the Presence of Cryptic Species within the T. indicum Species Complex. PLoS ONE 2013, 8, e82353. [CrossRef] [PubMed]

36. Belfiori, B.; Riccioni, C.; Paolocci, F.; Rubini, A. Characterization of the reproductive mode and life cycle of the whitish truffle T. borchii. Mycorrhiza 2016, 26, 515-527. [CrossRef]

37. Schneider-Maunoury, L.; Leclercq, S.; Clément, C.; Covès, H.; Lambourdière, J.; Sauve, M.; Richard, F.; Selosse, M.-A.; Taschen, E. Is Tuber melanosporum colonizing the roots of herbaceous, non-ectomycorrhizal plants? Fungal Ecol. 2018, 31, 59-68. [CrossRef]

38. Gryndler, M.; Černá, L.; Bukovská, P.; Hršelová, H.; Jansa, J. Tuber aestivum association with non-host roots. Mycorrhiza 2014, 24, 603-610. [CrossRef]

39. Leonardi, P.; Murat, C.; Puliga, F.; Iotti, M.; Zambonelli, A. Ascoma genotyping and mating type analyses of mycorrhizas and soil mycelia of Tuber borchii in a truffle orchard established by mycelial inoculated plants. Environ. Microbiol. 2020, 22, 964-975. [CrossRef]

40. Schneider-Maunoury, L.; Taschen, E.; Richard, F.; Selosse, M.-A. Soil spore bank in Tuber melanosporum: Up to $42 \%$ of fruitbodies remain unremoved in managed truffle grounds. Mycorrhiza 2019, 29, 663-668. [CrossRef]

41. Selosse, M.-A. Truffles. Curr. Biol. 2020, 30, R382-R383. [CrossRef]

42. Linde, C.C.; Selmes, H. Genetic Diversity and Mating Type Distribution of Tuber melanosporum and Their Significance to Truffle Cultivation in Artificially Planted Truffiéres in Australia. Appl. Environ. Microbiol. 2012, 78, 6534-6539. [CrossRef] [PubMed]

43. Molinier, V.; Murat, C.; Baltensweiler, A.; Büntgen, U.; Martin, F.; Meier, B.; Moser, B.; Sproll, L.; Stobbe, U.; Tegel, W.; et al. Fine-scale genetic structure of natural Tuber aestivum sites in southern Germany. Mycorrhiza 2016, 26, 895-907. [CrossRef] [PubMed]

44. Rubini, A.; Riccioni, C.; Belfiori, B.; Paolocci, F. Impact of the competition between mating types on the cultivation of Tuber melanosporum: Romeo and Juliet and the matter of space and time. Mycorrhiza 2014, 24, 19-27. [CrossRef] [PubMed]

45. Merényi, Z.; Varga, T.; Hubai, A.G.; Pitlik, P.; Erős, Á.; Trappe, J.M.; Bratek, Z. Challenges in the delimitation of morphologically similar species: A case study of Tuber brumale agg. (Ascomycota, Pezizales). Mycol. Prog. 2017, 16, 613-624. [CrossRef]

46. Marozzi, G.; Benucci, G.M.N.; Suriano, E.; Sitta, N.; Raggi, L.; Lancioni, H.; Falini, L.B.; Albertini, E.; Donnini, D. Tuber mesentericum and Tuber aestivum truffles: New Insights Based on Morphological and Phylogenetic Analyses. Diversity 2020, 12, 349. [CrossRef]

47. Leonardi, M.; Salvi, D.; Iotti, M.; Rana, G.L.; Paz-Conde, A.; Pacioni, G. Multilocus Phylogeography of the Tuber mesentericum Complex Unearths Three Highly Divergent Cryptic Species. J. Fungi 2021, 7, 1090. [CrossRef]

48. Turkoglu, A.; Castellano, M.A.; Trappe, J.M.; Güngör, M.Y. Turkish truffles I: 18 new records for Turkey. Turk. J. Bot. 2015, 39, 359-376. [CrossRef]

49. Zhang, L.-F.; Yang, Z.L.; Song, D. A phylogenetic study of commercial Chinese truffles and their allies: Taxonomic implications. FEMS Microbiol. Lett. 2005, 245, 85-92. [CrossRef]

50. Kinoshita, A.; Nara, K.; Sasaki, H.; Feng, B.; Obase, K.; Yang, Z.L.; Yamanaka, T. Using mating-type loci to improve taxonomy of the Tuber indicum complex, and discovery of a new species, T. longispinosum. PLoS ONE 2018, 13, e0193745. [CrossRef]

51. Chen, J.; Li, J.-M.; Tang, Y.-J.; Xing, Y.-M.; Qiao, P.; Li, Y.; Liu, P.-G.; Guo, S.-X. Chinese Black Truffle-Associated Bacterial Communities of Tuber indicum From Different Geographical Regions with Nitrogen Fixing Bioactivity. Front. Microbiol. 2019, 10, 2515. [CrossRef] 
52. Nakamura, N.; Abe, J.P.; Shibata, H.; Kinoshita, A.; Obase, K.; Worth, J.R.P.; Ota, Y.; Nakano, S.; Yamanaka, T. Genotypic diversity of the Asiatic black truffle, Tuber himalayense, collected in spontaneous and highly productive truffle grounds. Mycol. Prog. 2020, 19, 1511-1523. [CrossRef]

53. Mello, A.; Ding, G.-C.; Piceno, Y.M.; Napoli, C.; Tom, L.M.; DeSantis, T.Z.; Andersen, G.L.; Smalla, K.; Bonfante, P. Truffle brûlés have an impact on the diversity of soil bacterial communities. PLoS ONE 2013, 8, e61945. [CrossRef]

54. Deveau, A.; Antony-Babu, S.; Le Tacon, F.; Robin, C.; Frey-Klett, P.; Uroz, S. Temporal changes of bacterial communities in the Tuber melanosporum ectomycorrhizosphere during ascocarp development. Mycorrhiza 2016, 26, 389-399. [CrossRef] [PubMed]

55. Le Roux, C.; Tournier, E.; Lies, A.; Sanguin, H.; Chevalier, G.; Duponnois, R.; Mousain, D.; Prin, Y. Bacteria of the genus Rhodopseudomonas (Bradyrhizobiaceae): Obligate symbionts in mycelial cultures of the black truffles Tuber melanosporum and Tuber brumale. SpringerPlus 2016, 5, 1085. [CrossRef]

56. Barbieri, E.; Ceccaroli, P.; Saltarelli, R.; Guidi, C.; Potenza, L.; Basaglia, M.; Fontana, F.; Baldan, E.; Casella, S.; Ryahi, O.; et al New evidence for nitrogen fixation within the Italian white truffle Tuber magnatum. Fungal Biol. 2010, 114, 936-942. [CrossRef] [PubMed]

57. Barbieri, E.; Guidi, C.; Bertaux, J.; Frey-Klett, P.; Garbaye, J.; Ceccaroli, P.; Saltarelli, R.; Zambonelli, A.; Stocchi, V. Occurrence and diversity of bacterial communities in Tuber magnatum during truffle maturation. Environ. Microbiol. 2007, 9, 2234-2246. [CrossRef]

58. Amicucci, A.; Barbieri, E.; Sparvoli, V.; Gioacchini, A.M.; Calcabrini, C.; Palma, F.; Stocchi, V.; Zambonelli, A. Microbial and pigment profile of the reddish patch occurring within Tuber magnatum ascomata. Fungal Biol. 2018, 122, 1134-1141. [CrossRef]

59. Gryndler, M.; Soukupová, L.; Hršelová, H.; Gryndlerová, H.; Borovička, J.; Streiblová, E.; Jansa, J. A Quest for indigenous truffle helper Prokaryotes: Tuber aestivum-associative Prokaryotes. Environ. Microbiol. Rep. 2013, 5, 346-352. [CrossRef]

60. Splivallo, R.; Vahdatzadeh, M.; Macia-Vicente, J.G.; Molinier, V.; Peter, M.; Egli, S.; Uroz, S.; Paolocci, F.; Deveau, A. Orchard Conditions and Fruiting Body Characteristics Drive the Microbiome of the Black Truffle Tuber aestivum. Front. Microbiol. 2019, 10, 1437. [CrossRef]

61. Barbieri, E.; Bertini, L.; Rossi, I.; Ceccaroli, P.; Saltarelli, R.; Guidi, C.; Zambonelli, A.; Stocchi, V. New evidence for bacterial diversity in the ascoma of the ectomycorrhizal fungus Tuber borchii Vittad. FEMS Microbiol. Lett. 2005, 247, 23-35. [CrossRef]

62. Liu, D.; Chater, C.C.; Yu, F.; Perez-Moreno, J. Tuber pseudohimalayense ascomata-compartments strongly select their associated bacterial microbiome from nearby pine forest soils independently of their maturation stage. Pedobiologia 2021, 87-88, 150743. [CrossRef]

63. Ye, L.; Li, Q.; Fu, Y.; Sourzat, P.; Tan, H.; Zou, J.; Zhang, B.; Li, X. Host species effects on bacterial communities associated with the fruiting bodies of Tuber species from the Sichuan Province in Southwest China. Mycol. Prog. 2018, 17, 833-840. [CrossRef]

64. Benucci, G.M.N.; Bonito, G.M. The Truffle Microbiome: Species and Geography Effects on Bacteria Associated with Fruiting Bodies of Hypogeous Pezizales. Microb. Ecol. 2016, 72, 4-8. [CrossRef] [PubMed]

65. Vahdatzadeh, M.; Deveau, A.; Splivallo, R. The role of the microbiome of truffles in aroma formation: A meta-analysis ap-proach. Appl. Environ. Microbiol. 2015, 81, 6946-6952. [CrossRef] [PubMed]

66. Splivallo, R.; Deveau, A.; Valdez, N.; Kirchhoff, N.; Frey-Klett, P.; Karlovsky, P. Bacteria associated with truffle-fruiting bodies contribute to truffle aroma. Environ. Microbiol. 2015, 17, 2647-2660. [CrossRef]

67. Molinier, V.; Murat, C.; Frochot, H.; Wipf, D.; Splivallo, R. Fine-scale spatial genetic structure analysis of the black truffle Tuber aestivum and its link to aroma variability. Environ. Microbiol. 2015, 17, 3039-3050. [CrossRef] [PubMed]

68. Splivallo, R.; Valdez, N.; Kirchhoff, N.; Ona, M.C.; Schmidt, J.; Feussner, I.; Karlovsky, P. Intraspecific genotypic variability determines concentrations of key truffle volatiles. New Phytol. 2012, 194, 823-835. [CrossRef] 